DOI: $10.19195 / 0080-3626.61 .15$

JAKUB MACIEJ ŁUBOCKI

\title{
CZY SŁOWNIKI I ENCYKLOPEDIE SĄ ŹRÓDŁAMI INFORMACJI O CHARAKTERZE POCHODNYM?
}

Niedawno został opublikowany artykuł ${ }^{1}$ autora tych słów, który dotyczył strat, jakie ponosi specjalistyczny warsztat informacyjny z powodu nieuważnej i nieprzemyślanej automatyzacji pochodnych źródeł informacji (bibliografii/katalogów, słowników, encyklopedii). W trakcie procesu recenzyjnego zwrócono autorowi uwagę, że używanie terminu 'pochodne źródła informacji' (PŹI) w stosunku do słowników i encyklopedii jest dyskusyjne i postawiono pytanie: „Co jest tutaj źródłem pierwotnym? Jakie relacje zachodzą pomiędzy źródłami pierwotnymi a pochodnymi? Są to inne relacje, niż między dokumentem pierwotnym a bibliografią. Na przykład słownik i encyklopedia w bibliotekarstwie są dokumentami pierwotnymi. Autor używa więc terminu PŹI w innym znaczeniu, niż jest stosowane w bibliotekarstwie". Jest to pytanie bardzo istotne. Niestety, w pierwotnym artykule nie było już miejsca na dygresję mieszczącą objaśnienie tego zagadnienia: to znacznie powiększyłoby objętość i tak już rozbudowanego artykułu, ale przede wszystkim zagadnienie to leżało zbyt daleko od głównego toku wywodu, aby dało się je spójnie i bez szkody dla jasności przekazu w ten tok włączyć. Nie zmienia to faktu, że pytanie, czy słowniki i encyklopedie są PŹI, a jeśli tak, to co jest dla nich źródłem pierwotnym, nadal zasługuje na odpowiedź, albowiem nie jest ona tak oczywista, jak może się zdawać. Stąd autor postanowił udzielić jej w osobnym tekście. Oto on.

$* * *$

Przede wszystkim należy zaznaczyć, że PŹI jest pojęciem z obszaru teorii informacji naukowej $i$, nawet jeśli ma ono odmienne znaczenie na gruncie bibliotekarstwa, to jeśli pojawia się bez dalszych dopowiedzeń, należy przyjąć, że

1 J.M. Lubocki, Stare przestrzenie informacji. Co tracimy na niewłaściwej automatyzacji pochodnych źródet informacji?, „Roczniki Biblioteczne” 60, 2016, s. 315-344. 
jest używane w rozumieniu przyjętym przez ten obszar. Trzeba także zauważyć możliwość nieporozumienia, które czai się w podobieństwie dwóch terminów 'źródła pochodne' i 'źródła pośrednie'. Terminy te, tak jak i termin 'pochodne źródła informacji', są ściśle powiązane z zagadnieniami typologii dokumentów (a w niej: typologii źródeł informacji). Systematyka źródeł informacji, dokonana przez Wojciecha Piroga, dzieli dokumentalne źródła informacji na pierwotne, wtórne i pochodne. Różnicę między nimi autor definiuje następująco: „Dokument pierwotny zawiera informację źródłową, zaś pochodny informację przetworzoną, opracowaną według ustalonych zasad"2 . Z kolei źródła pochodne dzieli na skierowujące (,do dokumentów pierwotnych”), zastępujące („dokumenty pierwotne”) i faktograficzne (,zawierające rzeczową informację, opracowaną na podstawie dokumentów pierwotnych w układzie dostosowanym do potrzeb użytkowników") ${ }^{3}$. Pierwszy podział jest podziałem według pierwszeństwa źródłowego informacji, drugi - ze względu na rodzaj wiadomości, znany jest on także jako podział na źródła bezpośrednie (u Piroga: faktograficzne) i pośrednie (tamże: skierowujące) ${ }^{4}$. „Przyjęte tutaj określenie »informator pośredni« utworzone zostało ze względu na najbardziej powszechną (najczęściej spełnianą) funkcję pośredniej drogi prowadzącej od opisu bibliograficznego (katalogowego, dokumentacyjnego) do wykorzystywania treści zawartych w opisywanych publikacjach" ${ }^{\circ}$ i faktycznie tak jest, że bibliografie pośredniczą między użytkownikiem a informacją docelową, natomiast słowniki i encyklopedie zazwyczaj podają informację docelową bez potrzeby sięgania po źródło pier wo tne. Natomiast wszystkie trzy typy źródeł są nadal źródłami pochodny mi, ponieważ jest to informacja przetworzona, odpowiednio przygotowana, opracowana w specyficznym układzie (stąd z PŹI się „,korzysta”, a nie „czyta”; uwagę na to zwracają Sitarska i Zasadowa: „Wydawnictwa takie [informacyjne - J.M.Ł.] służą doraźnym poszukiwaniom informacyjnym, a nie systematycznym studiom" 6 i wypowiadają się one zarówno o informatorach bezpośrednich, jak i pośrednich, tj. o ogóle wydawnictw informacyjnych, które systematyka Piroga umieszcza wśród źródeł pochodnych ${ }^{7}$ ). Przede wszystkim jednak dokumenty pochodne są sporządzane „,na podstawie dokumentu pierwotnego lub wtórnego w drodze opracowania analityczno-syntetycznego" ${ }^{\text {. }}$.

Odpowiadając więc na pytanie, co jest w słownikach i encyklopediach źródłem pierwotnym, należy stwierdzić, że jest to wszystko to, co posłużyło do opracowania artykułu hasłowego w encyklopedii lub słowniku. Na potrzeby encyklopedii

2 W. Piróg, Zagadnienia informacji i dokumentacji naukowej, Warszawa 1977, s. 24.

3 Ibidem, s. 42.

4 Te określenia preferują: A. Sitarska, H. Zasadowa, Specjalistyczne wydawnictwa informacyjne (problematyka i przeglad), Warszawa 1972, s. 7-8.

5 Ibidem, s. 8.

${ }^{6}$ Ibidem, s. 7.

7 W. Piróg, op. cit., s. 44.

8 Ibidem, s. 24. 
czy słownika najczęściej nie prowadzi się nowych, oryginalnych badań, a jedynie dokonuje syntezy wiedzy już istniejącej. Przykładowo: hasło Albania w encyklopedii będzie opisywać jej ustrój, położenie, gospodarkę, historię, kulturę i sztukę etc., ale nie będzie to wiedza ustalona w osobnych badaniach prowadzonych dla potrzeb encyklopedii, nikt dla ustalenia liczby ludności Albanii nie przeprowadzi spisu powszechnego, a jedynie sięgnie do odpowiednich danych statystycznych. W słownikach podobnie: znaczenie poszczególnych wyrazów będzie wynikać $\mathrm{z}$ ich kontekstu tworzonego przez całe zdanie pozyskane $\mathrm{z}$ jakiegoś zewnętrznego źródła, a nie z osobnych badań wskazujących na wykorzystywanie wyrazu w ten, a nie inny sposób przez jakąś badaną próbę. To, że źródła te najczęściej nie są uwidocznione (lub są ogólnikowo podane w bibliografii załącznikowej bądź w przedmowie), nie oznacza, że nie uczestniczyły w procesie pozyskiwania informacji do artykułu hasłowego. Często ślad tego procesu widzimy w bibliografii do danego artykułu w encyklopedii (por. niektóre hasła w Encyklopedii wiedzy o książce czy Nowej encyklopedii powszechnej $P W N$ ). Trudniej przy słowniku językowym wskazać taką podstawę, ale też nigdy słownik nie jest uznaniową fantazją leksykografa, a jego zeschematyzowaną opinią na temat znaczenia wyrazów na podstawie ich rzeczywistego użycia; dziś w tym celu mogą służyć korpusy danego języka, dawniej — kartoteki wypisów z literatury i prasy (por. 11-tomowy Stownik języka polskiego pod red. W. Doroszewskiego). Słowniki dokumentacyjne (tj. dokumentujące obraz języka w danym miejscu i czasie) bezspornie są dokumentami pochodnymi, słowniki mające cel normatywny mogą mieć ten charakter nieco zachwiany, ponieważ tu uznaniowo niektóre decyzje definicyjne mogą być podejmowane przez leksykografa i jedynie słowniki języków sztucznych (tworzonych od podstaw) można uznać za pierwotne, gdyż mają formę i treść przewidzianą oraz st w or zoną przez autora (por. języki wymyślone przez J.R.R. Tolkiena). Ostateczne rozstrzygnięcie problemu, czy słowniki i encyklopedie mają charakter pochodny czy pierwotny, jest uzależnione od stopnia oparcia na poprzednich źródłach. Może być on mniejszy bądź większy, ale ponieważ wydawnictwa tego rodzaju zawsze:

a) powstają „,w drodze opracowania analityczno-syntetycznego" daleko bardziej intensywnego, aniżeli ma to miejsce w monografiach czy artykułach oryginalnych lub nawet przeglądowych, i stanowią esencję wiedzy, a nie jej opis;

b) charakteryzuje je „opracowanie według ustalonych zasad”, daleko bardziej skodyfikowanych i sztywnych, aniżeli ma to miejsce w pracach o charakterze tekstu ciągłego;

c) służą „doraźnym poszukiwaniom informacyjnym, a nie systematycznym studiom",

to co do zasady autor tych słów uważa, że należy je traktować bardziej jak źródła informacji o charakterze pochodnym niż pierwotnym.

Podsumowując: bibliografie, słowniki i encyklopedie są źródłami pochodnymi, różniącymi się jedynie rodzajem podawanych wiadomości. Fakt, że w bi- 
bliotekarstwie dwa ostatnie z nich są traktowane jak pierwotne, nie zmienia tego stanu. Zwłaszcza że Encyklopedia współczesnego bibliotekarstwa polskiego ${ }^{9}$ (EWBP) umieszcza wydawnictwa informacyjne w haśle Źródta informacji wśród dokumentów pochodnych, a w osobnym haśle im poświęconym - Wydawnictwa informacyjne — podaje, że istnieją ich dwa rodzaje: „dostarczające bezpośrednio potrzebnych wiadomości, jak wszelkiego rodzaju encyklopedie i słowniki" oraz „kierujące do innych źródeł; do nich należą wszelkie bibliografie”, a zatem odtwarza systematykę Piroga oraz Sitarskiej i Zasadowej. Trzeba jednak przyznać, że ta sama encyklopedia w wymienionym haśle Źródła informacji encyklopedie ogólne i fachowe wymienia wśród źródeł pierwotnych. Jak więc widać, o rozbieżność nie trudno, nawet w tak szanowanym wydawnictwie jak EWBP. Bibliotekarskie podejście do klasyfikacji słowników i encyklopedii należy więc uznać za rozwiązanie ułatwiające korzystanie w praktyce $\mathrm{z}$ tego rodzaju wydawnictw w bibliotekach, natomiast nie może ono stanowić podstawy do rozstrzygnięć naukowych.

9 Encyklopedia współczesnego bibliotekarstwa polskiego, pod red. K. Głombiowskiego, B. Świderskiego i H. Więckowskiej, Wrocław 1976, s. 308, 325. 